\title{
Analisis Efektivitas dan Kontribusi Komponen Pajak PKB. BBNKB dan PBBKB Terhadap Pendapatan Asli Daerah Provinsi Jambi Periode Tahun 2016 - 2018
}

\author{
Fathiyah, Mufidah, Masnun \\ Fakultas Ekonomi Universitas Batanghari Jambi \\ Correspondence email: fathiyahzaky74@gmail.com,mufidahjufri@gmail.com, masnunthojib@gmail.com
}

\begin{abstract}
Abstrak. This research aims to analyze the effectiveness of revenue per type of local tax and its contribution to the region own source revenue (PAD) Jambi Province Year 2016 - 2018. The data used in this research is the secondary data taken from the budget Realization report on the financial statement of the provincial government of Jambi province year 2016 - 2018, then the data is processed using the effectiveness percentage formula Per type of tax and contribution percentage per tax type against PAD Jambi province. The results of this study concluded that the effectiveness of the admission per type of regional tax (PKB, BBNKB and $P B B K B)$ of the provincial government of Jambi overall entered in the criteria is very effective, although in the last two years for tax $B B N K B$ and $P B B K B$ less Effective but every year continues to increase improvement and in the third year reaches the magnitude of the target that is a trailer set or $>100 \%$ until the third year of 2018 entered in the criteria is very effective. As for the percentage of contributions per tax type (PKB, BBNKB, and PBBKB) to PAD Jambi Province in the last three years the achievement is below $60 \%$ with ineffective criteria. This indicates that the contribution per tax type is very small to the PAD and automatically the number of $P A D$ that are absorbed or received by the provincial government of Jambi in 2016 - 2018 very small, So that dependence of Jambi provincial government to transfer funds from the central government to finance the development is still very large.
\end{abstract}

Keywords : Taxes, PAD, Effectiveness, Contributions

\section{PENDAHULUAN}

Dalam rangka melaksanakan pembangunan daerah pastinya diperlukan dana yang sangat besar dan mencukupi, tentunya dana tersebut harus ada sumbernya yaitu dari penerimaan daerah. Salah satu sumber penerimaan daerah tersebut adalah dari Pendapatan Asli Daerah (PAD), Namun penerimaan yang bersumber dari PAD ini belum bisa sepenuhnya membiayai pembangunan daerah karena kontribusinya sangat kecil sehingga daerah juga membutuhkan sumber dana lain yang berasal dari pemerintah pusat yang nota bene jumlahnya memang sangat besar yaitu dana transfer. Sejak diberlakukannya otonomi daerah dimana sebagian kewenangan pemerintah pusat didesentralisasikan kepada pemerintah daerah timbul persoalan bahwa daerah dituntut juga untuk melakukan desentrasilasi fiscal artinya daerah juga harus mandiri secara keuangan untuk membiayai program dan kegiatan pembangunannya. PAD sebagai salah satu sumber pendapatan yang menjadi andalan daerah harus dapat memberikan kontribusi yang besar untuk itu. Pajak daerah adalah bagian dari komponen PAD yang bisa menyumbangkan kontiribusi tersebut. Dalam konteks ini penulis hanya meneliti tiga jenis pajak saja yang dianggap memberikan kontribusi yang cukup besar terhadap PAD yaitu pajak kendaraan bermotor (PKB), pajak Bea Balik Nama Kendaraan bermotor (BBNKB) dan pajak Bahan Bakar Kendaraan Bermotor (PBBKB).

Provinsi Jambi adalah salah satu daerah yang setiap tahun pembiayaan pembangunannya terus mengalami peningkatan, tentunya sumber pendapatan yang berasal dari PAD pun harus meningkat pula karena daerah tidak bisa sepenuhnya bergantung pada dana transfer dari pemerintah pusat. Maka agar penerimaan dari pajak daerah terus meningkat setiap tahunnya daerah perlu menerapkan efektifitas dan efisiensi dalam pemungutuan pajak sehingga semua potensi penerimaan pajak dapat digenjot untuk meningkatkan pendapatan daerah. Berikut ini adalah tebel yang mengambarkan perkembangan realisasi penerimaan pajak daerah Provinsi Jambi yaitu pajak PKB, BBNKB dan PBBKB serta total PAD dalam tiga tahun terakhir. 
Fathiyah et al, Analisis Efektivitas dan Kontribusi Komponen Pajak PKB. BBNKB dan PBBKB Terhadap Pendapatan Asli Daerah Provinsi Jambi Periode Tahun 2016 - 2018

Tabel 1

Perkembangan Realisasi Pajak PKB, BBNKB, PBBKB dan Total PAD Pemerintah Provinsi Jambi Periode 2016 - 2018

\begin{tabular}{lcrrrr}
\hline \multicolumn{1}{c}{ Komponen Pajak } & $\mathbf{2 0 1 6}(\mathbf{R p})$ & $\mathbf{2 0 1 7}(\mathbf{R p})$ & $\mathbf{\%}$ & $\mathbf{2 0 1 8}(\mathbf{R p})$ & \multicolumn{1}{c}{$\boldsymbol{\%}$} \\
\hline PKB & 339.443 .747 .598 & 416.706 .232 .791 & 22,76 & 444.056 .622 .162 & 6,56 \\
BBNKB & 243.963 .112 .550 & 329.507 .745 .800 & 35,06 & 406.098 .313 .000 & 23,24 \\
PBBKB & 249.250 .031 .331 & 300.364 .910 .839 & 20,51 & 332.619 .004 .479 & 10,74 \\
Total & 832.656 .891 .479 & 1.046 .578 .889 .430 & 25,69 & 1.182 .773 .939 .641 & 13,01 \\
Total PAD & $\mathbf{9 6 6 . 5 1 9 . 3 4 7 . 1 0 2}$ & $\mathbf{1 . 3 1 6 . 1 6 2 . 4 6 7 . 4 8 5}$ & $\mathbf{3 6 , 1 8}$ & $\mathbf{1 . 3 7 4 . 2 8 9 . 4 0 9 . 9 7 5}$ & $\mathbf{4 , 4 2}$ \\
\hline
\end{tabular}

Sumber : LRA Provinsi Jambi Tahun 2016 - 2018

Berdasarkan Tabel 1 diatas dapat disimpulkan bahwa secara nominal ketiga komponen pajak tersebut mengalami peningkatan, namun secara perkembangan di ketiga tahun terakhir mengalami penurunan begitu juga dengan total penerimaan PAD terjadi penurunan yang sangat tajam. Hal seperti Ini mengindikasikan bahwa ada masalah pada efektivitas penerimaan dari pajak daerah yang secara otomatis menyebabkan berkurang pula tingkat penerimaan total PAD dalam tiga tahun terakhir sehingga rasio penerimaan dari ketiga pajak ini beserta total PAD Provinsi Jambi menjadi lebih kecil dibandingkan dengan dua tahun sebelumnya. Penelitian tentang efektivitas dan kotribusi pajak terhadap PAD sudah pernah dilakukan sebelumnya yaitu oleh Daisy SM. Engka dan Steva Y.L Tumangkang dengan judul penelitian Kajian Efektivitas dan Kontribusi Pajak Terhadap PAD Kabupaten Minahasa Utara dengan hasil penelitian adalah Tingkat efektivitas seluruh komponen pajak daerah pada tahun 2010 - 2014 semuanya mengalami peningkatan. Penelitian berikutnya oleh Mourin M. Mosal dengan judul Analisis Efektivitas Kontribusi Pajak Parkir Terhadap Pendapatan Asli Daerah dan Penerapan Akuntansi di Kota Manado, hasil penelitiannya menyimpulkan bahwa Kontribusi pajak parker terhadap PAD Kota Manado sangat kurang dan tidak mencapai target yang sudah ditetapkan.

Berdasarkan pada penjelasan dan data pada table diatas serta penelitian sebelumnya penelit tertarik untuk melakukan penelitian dan menganalisis tentang seberapa besarkah efektivitas penerimaan yang berasal dari komponen pajak daerah lainnya yang dalam hal ini adalah tiga pajak utama yang menyumbang nilai cukup besar terhadap PAD Provinsi Jambi yaitu pajak PKB, BBNKB, dan PBBKB serta seberapa besarkah persentase kontribusinya terhadap penerimaan PAD Pemerintah Provinsi Jambi selama periode tiga tahun terakhir yaitu pada tahun 2016 - 2018.

\section{Landasan Teori}

\section{Definisi Umum Pajak dan Pajak Daerah}

Ilyas dan Burton (2011) mengutip beberapa pendapat para ahli tentang definisi pajak diantaranya Seomitro yang menyatakan bahwa pajak adalah iuran rakyatkepada kas negara berdasarkan undang-undang yang dapat dipaksakan dan tidak mendapat jasa timbal balik. Sedangkan definis pajak menurut Soemahamidjaja adalah iuran wajib berupa uang atau barang yang dipungut oleh penguasa berdasarkan norma-norma hukum guna menutup biaya produksi barang-barang dan jasa-jasa kolektif dalam mencapai kesejahteraan umum. Berdasarkan Peraturan Daerah Provinsi Jambi Nomor 6 Tahun 2011 tentang Pajak daerah, maka definisi pajak daerah adalah kontribusi wajib kepada daerah yang terutang oleh orang pribadi atau badan yang besifat memaksa berdasarkan undang-undang dengan tidak mendapatkan imbalan secara lansung dan digunakan untuk keperluan daerah bagi sebesar-besarnya kemakmuran rakyat.

\section{Fungsi Pajak}

Menurut Mardiasmo (2009) pajak dibagi menjadi 2 fungsi yaitu :

1. Fungsi Budgetair

Pajak sebagai sumber dana bagi pemerintah untuk membiayai pengeluarannya

2. Fungsi Reulered

Pajak sebagai alat untuk mengatur atau melaksanakan kebijakan pemerintah dalam bidang sosial dan ekonomi 


\section{METODE}

Data yang digunakan dalam penelitian ini adalah data sekunder yang diperoleh dari Laporan Realisasi Anggaran Pemerintah Provinsi Jambi yang terdapat dalam Dokumen Laporan Keuangan Pemerintah Provinsi Jambi pada tahun 2016 -2018. Kemudian data tersebut diolah dan dianalisis dengan menggunakan formula rasio efektivitas dan analisis kontribusi serta diinterpretasikan dengan literatur yang terkait.

Adapun alat analisis yang digunakan adalah sebagai berikut :

1. Rasio Efektivitas

Efektivitas Per Jenis Pajak (EPJP) $=\frac{\text { Realisasi Per Jenis Pajak }}{\text { Target Per Jenis Pajakk }} \times 100 \%$

2. Analisis Kontribusi

Kontribusi Per Jenis Pajak (KPJP) $=\frac{\text { Realisasi Per Jenis Pajak }}{\text { Realisasi PAD }} \times 100 \%$

\section{Jenis dan Definisi Pajak yang Dipungut Pemerintah Provinsi}

Pada pasal 2 Bab II Perda Provinsi Jambi tentang pajak daerah, adapun jenis pajak daerah yang dipungut oleh Provinsi adalah : Pajak Kendaraan Bermotor, Pajak Bea Balik Nama Kendaraan bermotor, Pajak Bahan Bakar Kendaraan Bermotor, Pajak Air Permukaan Tanah, dan Pajak Rokok. Pajak Kendaraan Bermotor (PKB) adalah pajak atas kepemilikan dan atau penguasaan kendaraan bermotor. Pajak Bea Balik Nama Kendaraan Bermotor (BBNKB) adalah pajak atas penyerahan hak milik kendaraan bermotor sebagai akibat perjanjian dua pihak atau perbuatan sepihak atau keadaan yang terjadi karena jual beli, tukar menukar, hibah, warisan, atau pemasukan kedalam badan usaha. Pajak Bahan Bakar kendaraan bermotor adalah pajak atas penggunaan bahan bakar kendaraan bermotor. Pajak Air Permukaan tanah adalah pajak atas pengambilandan/atau pemanfaatan air permukaan. Pajak Rokok adalah pungutan atas cukai rokok yang dipungut oleh pemerintah.

\section{Pendapatan Asli Daerah (PAD)}

Menurut Undang-undang nomor 33 Tahun 2004 menyatakan bahwa Pendapatan Asli Daerah adalah pendapatan yang diperoleh daerah yang dipungut berdasarkan Peraturan daerah sesuai dengan peraturan perundang-undangan. Sedangkan menurut Augustyas (2013) Pendapat Asli Daerah adalah sumber pendapatan daerah yang berasal dari kegiatan ekonomi daerah itu sendiri. Pendapatan Asli Daerah merupakan pilar kemadirian suatu daerah. Mahmudi (2010) mengutip dalam bukunya bahwa Sumber-sumber Pendapatan Asli Daerah berdasarkan Undang-undang nomor 33 Tahun 2004 adalah: Pajak Daerah, Retribusi Daerah, Bagian Laba Pengelolaan Aset Daerah yang dipisahkan, dan Lain-lain PAD yang sah

\section{Efektivitas}

Menurut Mahmudi (2010) efektivitas adalah hubungan antara keluaran dengan tujuan atau sasaran yang harus dicapai. Suatu kegiatan dianggap efektif apabila proses kegiatan mencapai tujuan dan sasaran akhir dengan tepat. Pajak daerah dapat dikatakan efektivitasnya memenuhi kriteria efektif atau tidak dengan tingkat capaian pada tabel 2 berikut ini

Tabel 2

Interpretasi Nilai Efektivitas

\begin{tabular}{lll}
\hline & Persentase & Kriteria \\
\hline $100 \%$ & & Sangat Efektif \\
$90 \%-100 \%$ & Efektif \\
$80 \%-90 \%$ & Cukup Efektif \\
$60 \%-805$ & Kurang Efektif & \\
$<60 \%$ & Tidak Efektif & \\
\hline
\end{tabular}

Sumber : Kepmendagri No. 690.900-327, Tahun 1996 (dalam Mahmudi, 2010) 
Fathiyah et al, Analisis Efektivitas dan Kontribusi Komponen Pajak PKB. BBNKB dan PBBKB Terhadap Pendapatan Asli Daerah Provinsi Jambi Periode Tahun 2016 - 2018

\section{Kontribusi}

Menurut Alwi (2007) dalam kamus besar bahasa Indonesia kontribusi artinyai adalah iuran uang atau sumbangan. Kontribusi diberikan seseorang untuk meningkatkan efisiensi dan efektivitas suatu kegiatan.

\section{HASIL}

Analisis Efektivitas Penerimaan Pajak PKB, BBNKB dan PBBKB Pemerintah Provinsi Jambi Tahun 2016 2018

Tabel 3

Persentase Efektivitas Per Jenis Pajak Pemerintah Provinsi Jambi Tahun 2016 - 2018

\begin{tabular}{|c|c|c|c|c|c|}
\hline Tahun & Jenis Pajak Kriteria & PKB & BBKB & PBBKB & Total \\
\hline \multirow{4}{*}{2016} & Target & 330.950 .000 .000 & 335.250 .830 .000 & 282.231 .166 .893 & 984.431 .996 .893 \\
\hline & Realisasi & 339.443 .747 .598 & 243.963 .112 .550 & 240.250 .031 .331 & 832.656 .891 .479 \\
\hline & Persentase & $102,57 \%$ & $72,77 \%$ & $88,31 \%$ & - \\
\hline & Kriteria & Sangat Efektif & Kurang Efektif & Cukup Efektif & - \\
\hline \multirow[t]{4}{*}{2017} & Target & 355.840 .448 .000 & 354.667 .552 .000 & 310.400 .000 .000 & 741.548 .000 .000 \\
\hline & Realisasi & 416.706 .232 .791 & 329.507 .745 .800 & 300.364 .910 .839 & 1.046 .578 .889 .430 \\
\hline & Persentase & $11710 \%$ & $92,91 \%$ & $96,77 \%$ & - \\
\hline & Kriteria & Sangat Efektif & Efektif & Efektif & - \\
\hline \multirow[t]{4}{*}{2018} & Target & 438.223 .861 .432 & 350.283 .133 .090 & 315.383 .156 .381 & 1.103 .890 .10 .903 \\
\hline & Realisasi & 444.056 .622 .162 & 406.098 .313 .000 & 332.619 .004 .479 & 1.182 .773 .939 .641 \\
\hline & Persentse & $101,33 \%$ & $115,93 \%$ & 105,47 & - \\
\hline & Kriteria & Sangat Efektif & Sangat Efektif & Sangat Efektif & - \\
\hline
\end{tabular}

Sumber : Data diolah

Pada Tabel 3 terlihat bahwa untuk penerimaan dari pajak PKB dalam tiga tahun terakhir dikategorikan dengan kriteria sangat efektif karena persentasenya semua diatas 100\% melampaui target yang telah ditetapkan, walaupun capaian realisasinya diatas $100 \%$ tetapi pada tahun ketiga terjadi penurunan pada realisasi penerimaannya hal ini mengindikasikan bahwa tingkat efektivitas penerimaan juga mengalamii penurunan. Untuk Pajak BBNKB dalam tiga tahun terakhir terus mengalami peningkatan dimana persentase efektivitas pencapaian pada tahun 2016 adalah sebesar 72,77\% dengan kriteria kurang efektif, selanjutnya pada tahun 2017 adalah sebesar 92,21\% dengan kriteria efektif dan pada tahun 2018 dengan capaian sebesar 115,93\% masuk kriteria Sangat efektif. Ini artinya bahwa efektivitas penerimaan pada komponen pajak ini semakin tahun sudah semakin baik atau semakin efektif. Terakhir adalah pajak PBBKB yang dalam tiga tahun terakhir juga mengalami peningkatan dengan persentase efektivitas pencapaian pada tahun 2016 adalah sebesar 88,31\% dengan kriteria cukup efektif, kemudian tahun 2017 sebesar 96,77\% dengan kirteria efektif, dan yang terakhir ditahun 2018 dengan capaian sebesar 105,47\% dengan kiteria sangat efektif karena melampaui target yang sudah ditetapkan. Sama seperti pajak BBNKB diatas penerimaan dari komponen pajak PBBKB tiap tahun juga terus mengalami peningkatan dan semakin efektif.

Analisis Kontribusi Per Jenis Pajak Terhadap PAD Pemerintah Provinsi Jambi Tahun 2016 - 2018

Tabel 4

Persentase Kontribusi Komponen Pajak PKB, BBNKB dan PBBKB terhadap PAD Provinsi Jambi Tahun 2016 - 2018

\begin{tabular}{|c|c|c|c|c|c|c|}
\hline $\begin{array}{c}\text { Tahun } \\
\text { Komponen Pajak }\end{array}$ & 2016 & Kontribusi & 2017 & Kontribusi & 2018 & Kontribusi \\
\hline PKB & 339.443 .747 .598 & $35,12 \%$ & 416.706 .232 .791$. & $31,66 \%$ & 444.056 .622 .162 & $32,31 \%$ \\
\hline Kriteria & \multicolumn{2}{|c|}{ Tidak Efektif } & \multicolumn{2}{|c|}{ Tidak Efektif } & \multicolumn{2}{|c|}{ Tidak Efektif } \\
\hline BBNKB & 243.963 .112 .550 & $25,24 \%$ & 329.507 .745 .800 & $25,04 \%$ & 406.098 .313 .000 & $29,55 \%$ \\
\hline Kriteria & \multicolumn{2}{|c|}{ Tidak Efektif } & \multicolumn{2}{|c|}{ Tidak Efektif } & \multicolumn{2}{|c|}{ Tidak Efektif } \\
\hline PBBKB & 249.250 .031 .331 & $25,78 \%$ & 300.364 .910 .839 & $22,82 \%$ & 332.619 .004 .479 & $24,20 \%$ \\
\hline Kriteria & \multicolumn{2}{|c|}{ Tidak Efektif } & \multicolumn{2}{|c|}{ Tidak Efektif } & \multicolumn{2}{|c|}{ Tidak Efektif } \\
\hline Total & 832.656 .891 .479 & $86,15 \%$ & 1.046 .578 .889 .430 & $79,52 \%$ & 1.182 .773 .939 .641 & $86,06 \%$ \\
\hline PAD & 966.519.347.102 & & 1.316.162.467.485 & & 1.374.289.409.975 & \\
\hline
\end{tabular}

Sumber : Data diolah 
Berdasarkan pada tabel 4 diatas dapat dilihat bahwa pada tahun 2016 kontibusi PKB terhadap PAD Provinsi Jambi adalah sebesar 35,12\%, Kontribusi Pajak BBNKB sebesar 25,24\% dan kontribusi pajak PBBKB adalah sebesar 25,78. Dikarenakan ketiga komponen pajak ini kontribusinya dibawah 60\% maka masuk dalam kategori kriteria tidak efektif. Walaupun kontribusi setiap komponen per jenis pajak nya masuk dalam kriteria tidak efektif, namun secara total gabungan jumlah ketiga pajak diatas memberikan kontribusi sebesar $86,15 \%$ terhadap PAD Provinsi Jambi dan dalam kategori kriteria cukup efektif. Perlu diketahui walaupun secara total keseluruhan jumlah pajak tersebut mencapai angka 86,15\% tetapi dengan jumlah PAD yang boleh dikategorikan sangat kecil maka angka tersebut diatas belum memberikan kontribusi yang sangat berarti, artinya untuk membiayai pembangunan belum bisa mengandalkan dari PAD yang sudah ada dan masih bergantung pada dana transfer dari pemerintah pusat. Pada tahun 2017 besaran kontribusi pajak PKB terhadap PAD Provinsi Jambi adalah 31,66\%, pajak BBNKB sebesar 25,04\% dan pajak PBBKB sebesar 22,82\%. Karena besaran kontribusinya semua dibawah $60 \%$ maka pada tahun ini semua jenis komponen pajak tersebut masuk dalam kriteria tidak efektif. Sama seperti penjelasan sebelumnya walaupun bila dijumlah total ketiga pajak tersebut mencapai sebesar 79,52\% namun belum memberikan kontribusi yang berarti dan sebaliknya justru terjadi penurunan besaran tingkat kontribusinya terhadap PAD di tahun ini. Berikutnya pada tahun 2018 kontribusi pajak PKB terhadap PAD Provinsi Jambi sebesar 32,31\%, pajak BBNKB sebesar 29,55\% dan pajak PBBKB adalah sebesar $24,20 \%$. Tidak berbeda dengan hasil perhitungan dua tahun sebelumnya dikarena nilai kontribusinya dibawah $60 \%$ maka masuk dalam kriteria tidak efektif. Penjelasan yang sama juga untuk jumlah total ketiga pajak tersebut yang memberikan kontribusi sebesar $86,06 \%$ berarti ada peningkatan dari tahun lalu sebesar $6,54 \%$. Artinya perkembangan tingkat kontribusi ketiga pajak tadi pada tiga tahun terakhir tidak begitu besar dan secara otomatis peningkatan PAD juga tidak begitu besar sehingga Pemerintah Provinsi Jambi masih sangat tergantung dengan bantuan dana dari pusat untuk membiayai pembangunannya.

\section{SIMPULAN}

Berdasarkan hasil penelitian dan pembahasan yang telah dilakukan dapat disimpulkan beberapa hal sebagai berikut :

a. Efektivitas Penerimaan pajak PKB dan dalam tiga tahun terakhir masuk dalam kriteria sangat efektif karena besaran efektivitas capaiannya semua diatas $100 \%$ melampaui target yang telah ditetapkan.

b. Efektivitas penerimaan pajak BBNKB dalam tiga tahun terakhir terus mengalami peningkatan dengan persentase capaian ditahun 2016 sebesar 72,77\% dengan kriteria kurang efektif, tahun 2017 meningkat menjadi sebesar 92,91\% dengan kriteria efektif dan ditahun 2018 persentase capaiannya meningkat lagi menjadi 115,93 masuk dalam kriteria sangat efektif.

c. Efektivitas penerimaan pajak PBBKB juga mengalami peningkatan dalam tiga tahun terakhir dimana persentase capaian efektivitasnya tahun 2016 sebesar 88,31\% dengan kriteria cukup efektif, tahun 2017 sebesar 96,77\% dengan kriteria efektif dan terakhir di tahun 2018 capaian efektivitasnya sebesar 105,47\% diatas target yang ditetapkan dengan kriteria sangat efektif.

d. Persentase kontribusi pajak PKB, BBNKB dan PBBKB terhadap PAD Provinsi Jambi dari tahun 2016 2018 semuanya berada pada posisi dibawah $60 \%$ berarti masuk dalam kriteria tidak efektif. Walaupun bila dijumlah total ketiga pajak tersebut mencapai kontribusi diatas $80 \%$, namun belum memberikan kontrribusi yang berarti karena PAD yang diterimapun nilainya juga sangat kecil sehingga Pemerintah Provinsi Jambi masih mempunyai ketergantungan dengan dana transfer dari pemerintah pusat dalam membiayai pembangunannya.

\section{DAFTAR PUSTAKA}

Alwi,Hasan, 2007. Kamus Besar Bahasa Indonesia. Balai Pustaka. Jakarta

Engka, Daisy S.M, Steeva Y.L. Tumangkeng, Kajian Efektivitas dan Kontribusi Pajak Terhadap PAD Kabupaten Minahasa Utara. Program Studi Ekonomi Pembangunan Fakultas Ekonomi dan Bisnis Universitas Sam Ratulangi. Manado 
Fathiyah et al, Analisis Efektivitas dan Kontribusi Komponen Pajak PKB. BBNKB dan PBBKB Terhadap Pendapatan Asli Daerah Provinsi Jambi Periode Tahun 2016 - 2018

Ilyas, W, Burton, R. 2011. Hukum Pajak. Salemba Empat. Jakarta

Mahmudi,. 2010. Analisis Laporan Keuangan Pemerintah Daerah. Sekolah Tinggi Ilmu Manajemen Yogyakarta

Mardiasmo, 2009. Perpajakan. Edisi Revisi. Andi. Yogyakarta

Mosal, Mourin.M. Analisis Efektivitas, Kontribusi Pajak Parkir Terhadap Pendapatan Asli Daerah (PAD) dan Penerapan Akuntansi di Kota Manado. Jurusan Akuntansi Fakultas Ekonomi dan Bisnis Universitas Sam Ratulangi. Manado

Peratutan Daerah Provinsi Jambi Nomor 6 Tahun 2011 Tentang Pajak Daerah

Peraturan Daerah Provinsi Jambi Nomor 6 Tahun 2018 tentang Perubahan Atas Peraturan Daerah Provinsi Jambi Nomor 6 Tahun 2011 Tentang Pajak Daerah

Republik Indonesia. Undang-undang Nomor 33 Tahun 2004 Tentang Perimbangan Keuangan Antara Pemerintah Pusat dan Pemerintah Daerah 